\title{
Pemberian Antijamur Empiris pada Keganasan dengan Demam Neutropenia Laporan Kasus
}

\author{
Anastasia Maureen, Endang Windiastuti \\ Departemen Ilmu Kesehatan Anak Fakultas Kedokteran Universitas Indonesia, RS Dr. Cipto \\ Mangunkusumo, Jakarta
}

\begin{abstract}
Risiko infeksi jamur meningkat pada pasien dengan neutropenia terutama anak dengan keganasan. Pemberian antijamur empiris pada pasien dewasa sudah sering dilakukan dengan tujuan untuk menurunkan angka morbiditas dan mortalitas terutama mereka dengan keganasan yang disertai demam berkepanjangan dan neutropenia. Belum didapatkan metode diagnosis infeksi jamur sistemik pada keadaan tersebut, namun pemberian antijamur dengan jelas memberikan keuntungan. Konsensus pemberian antijamur pada kasus anak dengan keganasan belum ada, untuk itu perlu penelusuran bukti berbasis medik yang memadai sehingga para praktisi onkologis anak dapat dengan benar memberikan antijamur empiris.

Sari Pediatri 2010;12(3):211-6.
\end{abstract}

Kata kunci: antijamur, anak, demam neutropenia, keganasan

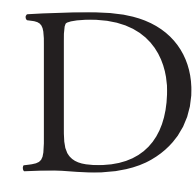
emam neutropenia sering dijumpai pada pasien keganasan. Komplikasi ini dapat terjadi primer atau sekunder akibat efek samping pengobatan. Neutropenia merupakan faktor risiko yang tinggi terjadinya infeksi bakteri dan jamur. ${ }^{1,2}$ Morbiditas dan mortalitas yang tinggi akibat infeksi bakteri menyebabkan pentingnya pemberian antibiotik empiris sedini mungkin.

Sepertiga pasien demam neutropenia yang tidak membaik dengan pemberian antibiotik selama satu minggu akan mengalami infeksi jamur invasif. ${ }^{1}$

\footnotetext{
Alamat korespondensi:

Dr. Endang Windiastuti, Sp.A(K). Divisi Hematologi Onkologi Departemen Ilmu Kesehatan Anak FKUI- RSCM Jl. Salemba no. 6, Jakarta 10430. Telp. 021-3907744, 31901170, Fax.021-3913982
}

Candida sp dan Aspergilus sp adalah dua jenis jamur tersering yang ditemukan. ${ }^{1,3-5}$ Angka mortalitas akibat kandidosis dan aspergilosis invasif pada anak masing-masing 19\%-31\% dan 68\%-77\%. ${ }^{4}$ Kesulitan penegakan diagnosis definitif dan tingginya morbiditas dan mortalitas akibat infeksi jamur invasif menyebabkan sebagian klinisi memberikan antijamur empiris. Efektivitas pemberian antijamur empiris pada demam neutropenia masih dipertanyakan. Empat kelompok antijamur yang digunakan untuk mengobati infeksi jamur invasif adalah polyene (amfoterisin B), azol (flukonazol, itrakonazol, vorikonazol, posakonazol), echinocandin (caspofungin, micafungin), dan analog nukleosida. ${ }^{4,6}$ Tujuan penulisan kasus berbasis bukti untuk mengevaluasi efektivitas pemberian antijamur empiris pada demam neutropenia. 


\section{Kasus}

Seorang anak perempuan, usia 7 tahun, datang ke Instalasi Gawat Darurat (IGD) Rumah Sakit Cipto Mangunkusumo (RSCM) dengan keluhan utama demam tinggi sejak dua hari sebelum masuk ke rumah sakit. Pasien didiagnosis leukemia limfoblastik akut (LLA) L-1 berdasarkan hasil aspirasi sumsum tulang dan sedang menjalani kemoterapi fase induksi minggu ke-dua dengan metotreksat intratekal, vinkristin dan daunorubisin intravena (IV). Demam timbul tujuh hari pasca-kemoterapi dengan suhu mencapai $40^{\circ} \mathrm{C}$, tidak ada gejala batuk, pilek, maupun muntah, dan asupan makanan berkurang. Buang air besar dan buang air kecil normal. Pasien tampak pucat namun tidak ada perdarahan spontan. Riwayat kehamilan, persalinan, dan tumbuh kembang normal sesuai usia. Imunisasi dasar lengkap dan asupan nutrisi sebelum sakit kesan normal.

Pada pemeriksaan fisis pasien tampak kompos mentis, tidak sesak maupun sianosis. Laju napas 30 kali/menit, teratur, dengan kedalaman cukup, laju nadi adalah $120 \mathrm{kali} / \mathrm{menit}$, teratur, dengan isi cukup, dan suhu aksila $38,4^{\circ} \mathrm{C}$. Berat badan pasien $21,5 \mathrm{~kg}$ $\left(\mathrm{P}_{50} \mathrm{CDC} 2000\right)$, tinggi badan $116 \mathrm{~cm}\left(\mathrm{P}_{10-25} \mathrm{CDC}\right.$ 2000), lingkar lengan atas (LLA) $16,6 \mathrm{~cm}$, LLA menurut umur $90,7 \%$, secara klinis dan antropometris, anak mempunyai gizi baik. Pada pemeriksaan mata konjungtiva tampak pucat. Pada pemeriksaan mulut tidak didapatkan oral thrush atau karies dentis. Kelenjar getah bening tidak teraba membesar. Pemeriksaan telinga, hidung, tenggorokan, jantung dan paru dalam batas normal. Hati teraba $4 \mathrm{~cm}$ bawah arkus kosta dan $3 \mathrm{~cm}$ bawah prosesus xifoideus, limpa Schuffner II. Akral teraba hangat dan perfusi perifer baik. Tidak tampak perdarahan kulit. Pemeriksaan laboratorium, $\mathrm{Hb} 8,5 \mathrm{~g} / \mathrm{dL}$, Ht $26 \%$, leukosit $600 / \mu \mathrm{L}$, trombosit $19.000 / \mu \mathrm{L}$, absolute neutrofil count (ANC) $200 / \mu \mathrm{L}$, MCV $81 \mathrm{fl}$ MCH 27 pg, MCHC 33 g/dL.

Pasien dirawat dengan diagnosis LLA L-1 dan demam neutropenia, diberikan antibiotik seftazidim $3 \times 500 \mathrm{mg}$ intravena, transfusi trombosit, dan direncanakan mendapat lanjutan kemoterapi fase induksi. Hari perawatan ke-tiga masih didapatkan demam tinggi sehingga dosis seftazidim ditingkatkan menjadi dosis sepsis, pada hari perawatan ke-4 diberikan antibiotik tambahan amikasin 1x400 mg intravena karena demam belum membaik. Hasil biakan darah steril dan biakan urin terdapat Escherichia coli $>100.000 \mathrm{kuman} / \mathrm{ml}$ yang sensitif terhadap amikasin. Pada hari perawatan ke-tujuh antibiotik diganti menjadi fosfomisin 2 x 1,5 g IV (sesuai hasil biakan dan resistensi urin). Hari perawatan ke-10 demam masih menetap, dilakukan work up infeksi ulang dengan hasil hemoglobin 9,1 g/dL, hematokrit $25,5 \%$, leukosit $500 / \mu \mathrm{L}$, trombosit $60.000 / \mu \mathrm{L}$, ANC $100 / \mu \mathrm{L}$, urinalisis dalam batas normal, prokalsitonin $78,07 \mathrm{ng} / \mathrm{mL}(\mathrm{N}<0,1)$. Pasien dikonsulkan ke Divisi Infeksi Tropis dan disarankan penggantian antibiotik menjadi meropenem. Pasien juga mendapat granulocyte colony stimulating factor (G-CSF) dengan dosis 5 $\mu \mathrm{g} / \mathrm{kg} /$ hari selama 4 hari. Pasca-pemberian G-CSF terdapat peningkatan leukosit menjadi $3300 / \mu \mathrm{L}$. Hari perawatan ke-15 pasien masih demam sehingga diberikan antijamur flukonazol 1 x $100 \mathrm{mg}$ intravena. Satu hari setelah pemberian flukonazol suhu cenderung turun. Pasien dipulangkan pada hari ke-empat pemberian antijamur setelah dua hari bebas demam. Hasil biakan darah tidak tumbuh jamur.

\section{Masalah klinis}

Praktik pemberian antijamur empiris pada demam neutropenia telah berlangsung lama. Keputusan pemberian antijamur umumnya berdasarkan menetapnya demam sesudah pemberian antibiotik spektrum luas yang adekuat. Sejauh ini belum ada konsensus mengenai efektivitas antijamur empiris pada demam neutropenia. Berdasarkan hal tersebut diformulasikan pertanyaan klinis sebagai berikut,

Pada anak dengan demam neutropenia, apakah pemberian antijamur empiris dapat menurunkan mortalitas? Apa golongan antijamur yang paling efektif?

\section{Metode/strategi penelusuran bukti}

Prosedur pencarian literatur untuk menjawab masalah klinis di atas adalah dengan menelusuri secara online menggunakan instrumen pencari Pubmed, Cochrane Library, Google, dan Yahoo. Kata kunci yang digunakan adalah " antifungal", "empiric", "febrile neutropenia", dan "children" dengan batasan penelitian dilakukan pada manusia, publikasi dalam bahasa Inggris, anak usia 0-18 tahun, kata kunci terdapat pada judul atau abstrak, serta jenis publikasi berupa uji klinis, uji klinis 
terandomisasi, meta-analisis, dan telaah sistematik.

Dengan metode tersebut, pada awalnya didapatkan 37 artikel yang memenuhi kriteria. Penelusuran lebih lanjut secara manual dilakukan pada daftar pustaka yang relevan. Setelah penelusuran judul dan abstrak artikel-artikel tersebut, didapatkan enam artikel yang relevan dengan masalah, terdiri dari satu meta-analisis, dan lima telaah sistematik.

Levels of evidence ditentukan berdasarkan klasifikasi yang dikeluarkan oleh Oxford Centre for Evidence-based Medicine Levels of Evidence. ${ }^{7}$

\section{Hasil penelusuran}

Sebagian besar subyek uji klinis dan telaah sistematik tentang pemberian antijamur empiris yang ada adalah gabungan dewasa dan anak. Hanya 1 penelitian antijamur empiris yang populasi seluruhnya anak. ${ }^{8}$ Tiga penelitian membandingkan antara antijamur empiris dan tanpa antijamur/plasebo dengan subyek anak dan dewasa, namun penelitian tersebut dilakukan 10-20 tahun yang lalu (Tabel 1$).^{9-11}$

Goldberg dkk, ${ }^{12} 2008$ melakukan meta-analisis terhadap 30 uji klinis terandomisasi tentang pemberian antijamur pada pasien keganasan yang mengalami demam neutropenia. Analisis dibagi menjadi empat kelompok. Luaran primer yang dinilai adalah angka mortalitas total dan insidens IJI, sedangkan luaran sekunder ialah composite failure (menetapnya demam, kegagalan mikrobiologik/breakthrough fungal infection, penghentian antijamur), mortalitas akibat IJI, dan efek samping obat.

Tujuh randomized controlled trial (RCT) membandingkan antara pemberian antijamur dan plasebo atau tanpa antijamur ( 6 penelitian) atau antijamur pre-emptive (1 penelitian). Definisi pre-emptive ialah bila antijamur diberikan secara selektif pada pasien dengan satu hasil pemeriksaan penunjang yang positif. Pemberian antijamur empiris tidak menurunkan angka mortalitas bila dibanding plasebo, tanpa antijamur atau antijamur pre-emptive (RR 0,82; 95\%IK 0,5-1,34), namun antijamur empiris dapat menurunkan angka kejadian IJI (RR 0,25; 95\%IK 0,12-0,54). Antijamur perlu diberikan kepada 17 orang untuk menghindari 1 kejadian IJI (NNT 17;95\%IK 11-33). Kelompok perlakuan memiliki composite failure (RR 0,71;95\% IK 0,59-0,85) dan angka mortalitas akibat IJI (RR $0,18 ; 95 \%$ IK $0,05-0,71)$ yang lebih rendah dibanding kelompok kontrol (NNT 33;95\%IK 17-100). ${ }^{12}$

Sepuluh RCT membandingkan antara antijamur golongan azol dan amfoterisin B. Angka mortalitas lebih rendah pada kelompok yang diberikan azol dibanding amfoterisin $\mathrm{B}$, namun hasil ini tidak bermakna secara statistik (RR 0,81;95\%IK 0,65-1,01). Tidak terdapat perbedaan bermakna risiko IJI antara kelompok azol dan amfoterisin B. Efek samping obat (nefrotoksisitas, hipokalemia, reaksi terkait infus) lebih sedikit dijumpai pada kelompok azol (RR 0,4;95\%IK 0,34-0,46). ${ }^{12}$

Sebelas RCT membandingkan antara bermacammacam sediaan amfoterisin $B$ yaitu amfoterisin $B$ konvensional (ABK), amfoterisin B liposomal (ABL), dan amphotericin $B$ lipid complex (ABLC). Kelompok $\mathrm{ABL}$ memiliki beberapa keuntungan yaitu angka

Tabel 1. Perbandingan efektivitas antijamur empiris pada demam neutropenia

\begin{tabular}{|c|c|c|c|c|c|}
\hline Uji Klinis & Subyek & $\begin{array}{c}\text { Desain } \\
\text { (Jumlah subyek) }\end{array}$ & Intervensi & Luaran & Hasil \\
\hline $\begin{array}{l}\text { Pizzo9 } \\
(1982)\end{array}$ & $\begin{array}{l}\text { Anak } \\
\& \\
\text { dewasa }\end{array}$ & $\begin{array}{c}\text { Open-label RCT } \\
(\mathrm{n}=34)\end{array}$ & $\begin{array}{c}\mathrm{CAB} \\
\text { vs } \\
\text { tanpa terapi }\end{array}$ & $\begin{array}{c}\text { Angka mortalitas } \\
\text { total } \\
\text { Kejadian IJI } \\
\text { Mortalitas akibat IJI }\end{array}$ & $\begin{array}{c}31 \% \text { vs } 38 \%(\mathrm{NS}) \\
6 \% \text { vs } 25 \% \\
6 \% \text { vs } 19 \%\end{array}$ \\
\hline $\begin{array}{l}\text { EORTC }^{10} \\
(1989)\end{array}$ & $\begin{array}{l}\text { Anak } \\
\& \\
\text { dewasa }\end{array}$ & $\begin{array}{c}\text { Open-label RCT } \\
(\mathrm{n}=157)\end{array}$ & $\begin{array}{c}\mathrm{CAB} \\
\text { vs } \\
\text { tanpa terapi }\end{array}$ & $\begin{array}{c}\text { Angka mortalitas } \\
\text { total } \\
\text { Kejadian IJI } \\
\text { Mortalitas akibat IJI } \\
\text { Respons klinis }\end{array}$ & $\begin{array}{c}16 \% \text { vs } 21 \%(\mathrm{NS}) \\
1,5 \% \text { vs } 6 \%(\mathrm{NS}) \\
0 \% \text { vs } 6 \%(\mathrm{p}=0,05) \\
65 \% \text { vs } 53 \%(\mathrm{p}=0,09)\end{array}$ \\
\hline $\begin{array}{l}\text { Wingard }^{11} \\
(1987)\end{array}$ & $\begin{array}{l}\text { Anak } \\
\& \\
\text { dewasa }\end{array}$ & $\begin{array}{c}\text { Double-blind RCT } \\
\quad(\mathrm{n}=208)\end{array}$ & $\begin{array}{l}\text { Mikonazol } \\
\text { vs } \\
\text { plasebo }\end{array}$ & $\begin{array}{l}\text { Fungal sepsis } \\
\text { Mortalitas akibat } \\
\text { Fungal sepsis }\end{array}$ & $\begin{array}{l}1 \% \text { vs } 7 \%(\mathrm{p}=0,03) \\
0 \% \text { vs } 50 \%(\mathrm{p}=0,08)\end{array}$ \\
\hline
\end{tabular}

$\mathrm{CAB}=$ conventional amphoterinin B deoxycholate; EORTC= European Organization for Research and Treatment of Cancer; IJI= infeksi jamur invasif 
mortalitas total dan angka kejadian IJI paling rendah dan efek samping obat paling sedikit dibanding kelompok amfoterisin B lainnya. Secara umum, angka kejadian IJI (RR 1,49;95\%IK 0,99-2,24) dan efek samping obat (RR 2,79;95\%IK 1,94-4,01) lebih tinggi dijumpai pada kelompok ABK. Dua RCT membandingkan antara caspofungin dan ABL. Angka mortalitas total dan angka kejadian IJI tidak berbeda bermakna antara kedua kelompok tersebut namun lebih sedikit efek samping yang dijumpai pada kelompok caspofungin (RR 0,79;95\%IK 0,72-0,87). Kelemahan utama dari penelitian tersebut ialah analisis per protokol, desain tidak tersamar, dan definisi IJI yang tidak seragam. ${ }^{12}$

Telaah sistematik yang dilakukan oleh Gotzche dan Johansen ${ }^{5}$ mendapatkan hasil yang berbeda. Telaah dilakukan terhadap 32 uji klinis terandomisasi untuk menilai efek pemberian antijamur empiris maupun profilaksis untuk menurunkan angka mortalitas akibat neutropenia pada pasien keganasan. Didapatkan amfoterisin $\mathrm{B}$ empiris atau profilaksis menurunkan angka mortalitas total (RR 0,69;95\%IK 0,5-0,96) dan angka kematian akibat infeksi jamur (RR 0,45;95\%IK 0,26$0,76)$ secara bermakna. Insidens IJI menurun dengan pemberian amfoterisin B, flukonazol, itrakonazol, namun tidak demikian halnya dengan ketokonazol dan mikonazol. Flukonazol terbukti menurunkan kematian akibat infeksi jamur (RR 0,42;95\%IK 0,24-0,73).

Perbedaan efektivitas berbagai antijamur untuk menurunkan angka mortalitas pada anak yang dicurigai (suspected) dan terbukti (proven) menderita IJI dirangkum dalam telaah sistematik yang dilakukan Blyth dkk. ${ }^{13}$ Suspected ialah anak dengan neutropenia disertai demam berkepanjangan sedangkan proven apabila gejala klinis infeksi jamur disertai bukti radiologik atau histopatologik atau mikrobiologik. Empat uji klinis membandingkan antara amfoterisin B formulasi lipid dan $\mathrm{ABK}$, dua uji klinis antara amfoterisin B formulasi lipid dan echinocandin, dan satu uji klinis antara flukonazol dan itrakonazol. Didapatkan tidak terdapat perbedaan efektivitas dan efek samping total berbagai antijamur tersebut. Efek samping nefrotoksisitas lebih sedikit dijumpai pada kelompok amfoterisin B formulasi lipid dibanding konvensional (RR 0,43;95\%IK 0,21-0,90), sehingga Blyth $\mathrm{dkk}^{13}$ menyarankan pemberian amfoterisin $\mathrm{B}$ formulasi lipid dibanding konvensional.

Marchetti $\mathrm{dkk}^{14}$ membuat review yang bertujuan mengetahui praktik klinis pemberian antijamur di Eropa dan menyusun guidelines berbasis bukti. Kuesio- ner digunakan sebagai alat untuk mengetahui praktik pemberian antijamur empiris. Sebanyak $97 \%$ ahli memberikan antijamur empiris sebagai prosedur standar pada demam neutropenia. Median waktu dimulainya antijamur berbeda antara episode pertama demam dan relaps ( 5 hari vs 3 hari; $\mathrm{p}<0,001$ ). Lima puluh persen ahli berpendapat pemberian antijamur empiris harus ditunda pada kasus yang terbukti infeksi bakteri dibanding kasus demam yang tidak dapat dijelaskan $(6,5$ hari vs 4 hari; $\mathrm{p}<0,001)$. Gambaran klinis mempengaruhi pemilihan antijamur. $\mathrm{ABK}$ digunakan pada kasus demam yang tidak dapat dijelaskan penyebabnya sedangkan caspofungin dan flukonazol menjadi pilihan pada kasus enterokolitis atau kolonisasi saluran cerna oleh Candida. Preparat ABL atau caspofungin dipilih untuk pasien yang kondisinya tidak stabil. Rasionalisasi pemberian antijamur empiris pada demam neutropenia persisten sama dengan antibiotik empiris yaitu mengurangi mortalitas akibat infeksi dengan memberikan terapi sedini mungkin. Waktu inisiasi antijamur ini beragam, berdasarkan kuesioner yang dilakukan terhadap klinisi di Eropa, median waktu dimulainya antijamur adalah lima hari. ${ }^{14}$ Penelitian yang dibahas pada telaah ini memiliki rentang waktu inisiasi antijamur empiris satu hingga tujuh hari pasca-menetapnya demam.

\section{Pembahasan}

Definisi demam neutropenia adalah demam (suhu oral $\geq 38,3^{\circ} \mathrm{C}$ pada satu kali pengukuran atau suhu $\geq 38^{\circ} \mathrm{C}$ yang menetap $\geq 1 \mathrm{jam}$ ) disertai neutropenia (jumlah neutrofil $<500 \mathrm{sel} / \mathrm{mm}^{3}$ atau $<1000 \mathrm{sel} /$ $\mathrm{mm}^{3}$ dan diprediksi akan menurun mencapai $<500$ $\left.\mathrm{sel} / \mathrm{mm}^{3}\right) .{ }^{6}$ Risiko bakteremia pada anak dengan demam neutropenia tinggi yaitu 20\%-30\% namun mortalitasnya relatif lebih rendah dibanding dewasa yaitu 1\%. ${ }^{6}$ Selain infeksi, demam neutropenia dapat disebabkan oleh faktor non infeksi seperti transfusi darah, aktivitas tumor, pemberian kemoterapi dan granulocyte colony stimulating factor. ${ }^{3}$

Bakteri merupakan penyebab infeksi terbanyak dengan 60\%-70\% diantaranya ialah bakteri Gram positif. ${ }^{3,6}$ Basil Gram negatif dan jamur diisolasi dari $22 \%$ dan $5 \%$ pasien demam neutropenia. ${ }^{6}$ Infeksi jamur dan mikobakterium dihubungkan dengan demam neutropenia berat (jumlah neutrofil $<500 / \mu \mathrm{L}$ ), berlangsung lama ( $>10$ hari), penggunaan antibiotik spektrum luas atau antijamur profilaksis yang lama, dan 
transplantasi sumsum tulang/stem cells). Jamur dapat ditemukan pada 30\%-40\% biakan darah pasien yang demamnya masih menetap setelah hari ke-lima. ${ }^{3}$

Tata laksana demam neutropenia memerlukan pendekatan multifaktor, diantaranya pemberian antibiotik yang adekuat, pemberian obat untuk meningkatkan imunitas seperti granulocyte colony stimulating factor, dan tata laksana suportif. Faktor risiko infeksi pada demam neutropenia dibagi menjadi tiga yaitu risiko rendah bila lama neutropenia $\leq 5$ hari dan tanpa salah satu faktor risiko infeksi bakteri invasif, (1) PCR serum $\geq 90 \%$,(2) hipotensi arterial,(3) leukemia relaps, (4) trombosit $<50.000 / \mathrm{mm}^{3}$,(5) jarak antara kemoterapi terakhir dan awitan demam $<7$ hari, risiko sedang bila lama neutropenia antara 6 sampai 9 hari, dan risiko tinggi bila lama neutropenia $\geq 10$ hari. $^{3}$

Neutropenia persisten merupakan faktor risiko tinggi IJI. ${ }^{15}$ Persentase infeksi jamur pada demam neutropenia persisten $15 \%-40 \% .^{12}$ Faktor risiko IJI lainnya pada pasien demam neutropenia ialah leukemia relaps dan menetapnya demam sesudah pemberian antibiotik

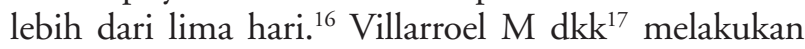
studi prospektif yang melibatkan multisenter untuk mengetahui faktor risiko IJI pada pasien keganasan dan demam neutropenia. Kesimpulannya, demam yang menetap pada hari ke-empat perawatan disertai absolute monocyte count $\leq 100 / \mu \mathrm{L}$ dan $C$-reactive protein $\geq 90$ $\mathrm{mg} / \mathrm{L}$, meningkatkan faktor risiko IJI secara bermakna (RR 5,2;95\%IK 3,4-8).

Diagnosis IJI sulit ditegakkan, demam dapat menjadi satu-satunya tanda, bahkan pada kasus infeksi Candida diseminata yang terbukti (proven) biakan darahnya steril. ${ }^{15}$ Pemberian antijamur empiris pada pasien neutropenia yang demamnya menetap merupakan prosedur standar yang berlangsung sejak dahulu., ${ }^{4,12}$ Empat puluh sampai $50 \%$ pasien neutropenia risiko tinggi mendapat terapi antijamur. ${ }^{12}$ Justifikasi terapi antijamur empiris pada demam neutropenia persisten ialah keberhasilan terapi antibiotik empiris, peningkatan mortalitas akibat IJI apabila pemberian antijamur ditunda, dan sulitnya mendiagnosis dini IJI. ${ }^{18}$

Amfoterisin B masih merupakan baku emas terapi IJI pada anak dan dewasa. Obat ini terikat pada ergosterol yaitu komponen utama membran sitoplasma jamur, selanjutnya mengubah permeabilitas dinding sel, mengakibatkan lisis sel jamur dan akhirnya kematian sel. Efek samping utama berkaitan dengan reaksi infus (infuse related events) dan toksisitas ginjal. ${ }^{19}$

Azol bekerja dengan cara menghambat kerja enzim
$14 \alpha$-demetilase yang mengatalisis biosintesis ergosterol. Flukonazol bersifat fungistatik sedangkan itrakonazol bersifat fungisidal. Vorikonazol adalah golongan azol generasi ke-dua yang mempunyai spektum antifungal luas seperti itrakonazol dan bioavailibilitas tinggi menyerupai flukonazol. Efek samping utama vorikonazol ialah gangguan penglihatan yang reversible, peningkatan enzim transaminase dan reaksi kulit. ${ }^{19}$ Vorikonazol lebih superior dibanding amfoterisin B untuk mengobati aspergilosis. ${ }^{18,19}$

Pada kasus kami pasien tergolong risiko tinggi karena lama neutropenia $\geq 10$ hari dan terdapat sedikitnya dua faktor risiko infeksi bakteri invasif yaitu trombosit $<50.000 / \mu \mathrm{L}$ dan awitan demam lebih dari tujuh hari sejak kemoterapi. Setelah pemberian berbagai jenis antibiotik yang sesuai dengan hasil biakan dan resistensi urin ternyata demam masih menetap sehingga antijamur ditambahkan pada hari ke-limabelas. Kepustakaan umumnya menganjurkan pemberian antijamur empiris lebih cepat yaitu lima hari setelah pemberian antibiotik demam dan neutropenia masih menetap. ${ }^{6}$ Pemilihan flukonazol intravena berdasarkan pertimbangan harga, kemudahan pemberian dan efek samping yang lebih sedikit dibanding amfoterisin B. Efektivitas flukonazol sama dengan amfoterisin $\mathrm{B}$, namun aktivitasnya terhadap Candida glabrata, Candida krusei dan Aspergillus sangat terbatas. ${ }^{20}$ Flukonazol sebaiknya tidak diberikan sebagai terapi empiris bila terdapat infiltrat di paru atau sudah diberikan sebagai profilaksis sebelumnya. ${ }^{21}$

\section{Kesimpulan}

Pada pasien anak, belum ada bukti berbasis medik yang memadai untuk menyimpulkan bahwa pemberian antijamur empiris pada demam neutropenia dapat menurunkan angka mortalitas. Beberapa studi yang ada melibatkan pasien dari segala usia ${ }^{5-9,14,20}$ atau menggabungkan terapi empiris, profilaksis ${ }^{5,20}$, dan definitif, sehingga kurang tepat menggunakannya untuk menjawab pertanyaan klinis. Namun demikian, karena kesulitan mendiagnosis dan mortalitas yang tinggi akibat infeksi jamur invasif, sebaiknya anak dengan demam neutropenia yang menetap lebih dari lima hari setelah pemberian antibiotik yang adekuat, juga diberikan antijamur empiris.

Jenis antijamur sistemik yang saat ini tersedia di Indonesia terbatas, yang tersering digunakan pada anak 
ialah amfoterisin B dan flukonazol. Walaupun terdapat banyak efek samping, amfoterisin B memiliki spektrum antijamur yang lebih luas dari flukonazol dan studi yang ada menyatakan amfoterisin B merupakan satu-satunya antijamur yang terbukti dapat menurunkan angka mortalitas. Secara ideal digunakan amfoterisin B formulasi lipid yang mempunyai efektivitas sama namun kurang efek sampingnya dibandingkan amfoterisin B konvensional. Sayangnya obat tersebut tidak tersedia di Indonesia. Penelitian lanjutan pada populasi anak diperlukan untuk menentukan waktu inisiasi dan jenis antijamur yang tepat sebagai terapi empiris pada demam neutropenia.

\section{Daftar pustaka}

1. Aygun B. Supportive care and management of oncologic emergencies. Dalam: Lanzkowsky P, penyunting. Manual of Pediatric Hematology and Oncology. Edisi ke-4. San Diego: Elsevier; 2005.h.695-748.

2. Windiastuti E. Antibiotik pada demam neutropenia. Dalam: Tumbelaka AR, Trihono PP, Kurniati N, Widodo DP, penyunting. Pendidikan Kedokteran Berkelanjutan Ilmu Kesehatan Anak XLVII: Penanganan Demam pada Anak Secara Profesional. Edisi ke-Jakarta: Departemen Ilmu Kesehatan Anak FKUI-RSCM; 2005.h.42-50.

3. Mendes AVA, Sapolnik R, Mendoca N. New guidelines for the clinical management of febrile neutropenia and sepsis in pediatric oncology patients. J Pediatr 2007;83:54-63.

4. Blyth CC, Palasanthiran P, O'Brien TA. Antifungal therapy in children with invasive fungal infection: a systematic review. Pediatrics 2007;119:772-84.

5. Gotzsche PC, Johansen HK. Routine versus selective antifungal administration for control of fungal infections in patients with cancer. Cochrane Database of Systematic Reviews 2009.

6. Immune deficiency. Dalam: Isaacs D, penyunting. Evidence-based Pediatric Infectious Diseases. Edisi ke-1. Massachusetts: Blackwell Publishing; 2007.h.117-25.

7. Oxford Centre of Evidence-based Medicine. Oxford Centre for Evidence-based Medicine Levels of Evidence (March 2009). Diunduh dari: http://www.cebm .net/index. aspx?o=1025.

8. Sandler ESM, Mustafa MM, Tkaczewski IRN, Graham ML, Morrison VA, Green M dkk. Use of amphotericin B colloidal dispersion in children. J Pediatr Hematol Oncol 2000;22:242-6.

9. Pizzo PA, Robichaud KJ, Gill FA, Witebsky FG. Empiric antibiotic and antifungal therapy for cancer patients with prolonged fever and granulocytopenia. Am J Med 1982;72:101-11.

10. EORTC International Antimicrobial Therapy Cooperative Group. Empiric antifungal therapy in febrile granulocytopenic patients. Am J Med 1989;86:672.

11. Wingard JR, Vaughn WP, Braine HG, Merz WG, Saral R. Prevention of fungal sepsis in patients with prolonged neutropenia: a randomized, double-blind, placebocontrolled trial of intravenous miconazole. Am J Med 2010;83:1103-10.

12. Goldberg E, Gafter-Gvili G, Robenshtok E, Leibovici L, Paul M. Empirical antifungal therapy for patients with neutropenia and persistent fever: systematic review and meta-analysis. Eur J Cancer 2008;44:2192-203.

13. Blyth CC, Hale K, Palasanthiran P, O'Brien T, Bennett MH. Antifungal therapy in infants and children with proven, probable or suspected invasive fungal infections. Cochrane Database of Systematic Review 2010.

14. Marchetti O, Cordonnier C, Calandra T. Empirical antifungal therapy in neutropaenic cancer patients with persistent fever. Eur J Cancer Supp 2007;5:32-42.

15. Alexander SW, Pizzo PA. Special consideration in children with fever and neutropenia. Dalam: Rolston K, Rubenstein EB, penyunting. Febrile Neutropenia. Edisi ke-1. London: Martin Dunitz Ltd; 2001.h.201-14.

16. Meckler G, Lindemulder S. Fever and neutropenia in pediatric patients with cancer. Emerg Med Clin North Am 2009;27:525-44.

17. Villarroel M, Aviles CL, Silva P, Guzman AM, Poggi H, Alvarez AM dkk. Risk factors associated with invasive fungal disease in children with cancer and febrile neutropenia: a prospective multicenter evaluation. Pediatr Infect Dis J 2010;29:816-21.

18. Klastersky J, Paesmans M. Antifungal therapy in febrile neutropenic patients: review of treatment choices and strategies for aspergillar infection. Support Care Cancer 2007;15:137-41.

19. Zaoutis TE, Benjamin DK, Steinbach WJ. Antifungal treatment in pediatric patients. Drug Resistance Updates 2005;8:235-45.

20. Johansen HK, Gotzsche PC. Amphotericin B versus fluconazole for controlling fungal infection in neutropenic cancer patients. Cochrane Database of Systematic Review 2002.

21. Link H, Bohme A, Cornely OA, Hoffken K, Kellner O, Kern WV dkk. Antimicrobial therapy of unexplained fever in neutropenic patients. Ann Hematol 2003;82 (Suppl 2):S105-17. 